\title{
T-type calcium channel antagonists, mibefradil and NNC-55-0396 inhibit cell proliferation and induce cell apoptosis in leukemia cell lines
}

\author{
Weifeng Huang ${ }^{1}$, Chunjing $\mathrm{Lu}^{2}$, Yong Wu', Shou Ouyang ${ }^{3}$ and Yuanzhong Chen ${ }^{1 *}$
}

\begin{abstract}
Background: T-type $\mathrm{Ca}^{2+}$ channels are often aberrantly expressed in different human cancers and participate in the regulation of cell cycle progression, proliferation and death. Methods: RT-PCR, Q-PCR, western blotting and whole-cell patch-clamp recording were employed to assess the expression of T-type $\mathrm{Ca}^{2+}$ channels in leukemia cell lines. The function of T-type $\mathrm{Ca}^{2+}$ channels in leukemia cell growth and the possible mechanism of the effect of T-type $\mathrm{Ca}^{2+}$ channel antagonists on cell proliferation and apoptosis were examined in T-lymphoma cell lines.

Results: We show that leukemia cell lines exhibited reduced cell growth when treated with T-type $\mathrm{Ca}^{2+}$ channel inhibitors, mibefradil and NNC-55-0396 in a concentration-dependent manner. Mechanistically, these inhibitors played a dual role on cell viability: (i) blunting proliferation, through a halt in the progression to the G1-S phase; and (ii) promoting cell apoptosis, partially dependent on the endoplasmic reticulum $\mathrm{Ca}^{2+}$ release. In addition, we observed a reduced phosphorylation of ERK1/2 in MOLT-4 cells in response to mibefradil and NNC-55-0396 treatment.
\end{abstract}

Conclusions: These results indicate that mibefradil and NNC-55-0396 regulate proliferation and apoptosis in T-type $\mathrm{Ca}^{2+}$ channel expressing leukemia cell lines and suggest a potential therapeutic target for leukemia.

Keywords: T-type calcium channels, Mibefradil, NNC-55-0396, Leukemia, Proliferation, Apoptosis

\section{Introduction}

Intracellular $\mathrm{Ca}^{2+}$ is a crucial secondary messenger that regulates many cellular processes, such as cell cycle progression, proliferation and apoptosis [1-3]. Intracellular $\mathrm{Ca}^{2+}$ levels are regulated by several mechanisms including plasma membrane ion channels (e.g., Voltage-gated and ligand-gated $\mathrm{Ca}^{2+}$ channels), ion exchangers and "pumps", as well as the release from the intracellular $\mathrm{Ca}^{2+}$ stores [3]. Orchestration of cytoplasm $\mathrm{Ca}^{2+}$ as evidenced by pulses, or oscillations, is crucial for cell cycle progression and therefore proliferation [4], otherwise, excessive $\mathrm{Ca}^{2+}$ or loss of control in $\mathrm{Ca}^{2+}$ signaling can lead to cell death [5]. In normal epithelial cells, free $\mathrm{Ca}^{2+}$ concentration is essential for cells to enter and accomplish the $\mathrm{S}$ phase and the $M$ phase of the cell cycle. Cancer cells are able to pass these phases with much lower extracellular $\mathrm{Ca}^{2+}$ levels than normal cells [6], indicating

\footnotetext{
* Correspondence: chenyz@mail.fjmu.edu.cn

${ }^{1}$ Fujian Institute of Hematology, Fujian Medical University Union Hospital,

Fuzhou 350004, People's Republic of China

Full list of author information is available at the end of the article
}

that they developed a more efficient mechanism to facilitate $\mathrm{Ca}^{2+}$ influx.

Among the routes for $\mathrm{Ca}^{2+}$ influx, T-type $\mathrm{Ca}^{2+}$ channel expression and relationship to proliferation and apoptosis have been demonstrated in many cancer types, including leukemic [7], ovarian [8, 9], glioma [10, 11], breast [12], esophageal [13], hepatoma [14], melanoma [15], and colon cancers [16]. Moreover, increased expression of T-type $\mathrm{Ca}^{2+}$ channels can be detected in tumor samples collected from patients. In addition, these reports also show that pharmacological inhibition by small molecule antagonists or RNAi-mediated downregulation of T-type $\mathrm{Ca}^{2+}$ channels leads to inhibition of cancer cell proliferation and inducing cancer cell apoptosis. Therefore, T-type $\mathrm{Ca}^{2+}$ channels pose an attractive potential target for cancer therapy. T-type $\mathrm{Ca}^{2+}$ channels have unique electrophysiological characteristics: low voltage-activated $\mathrm{Ca}^{2+}$ current, fast (transient) inactivation, slow deactivation and low unitary conductance [17]. To date, the existence of three different T-type $\mathrm{Ca}^{2+}$ channel subunits, the $\alpha 1 \mathrm{G}\left(\mathrm{Ca}_{\mathrm{v}} 3.1\right)$, $\alpha 1 \mathrm{H}\left(\mathrm{Ca}_{v} 3.2\right)$ and $\alpha 1 \mathrm{I}\left(\mathrm{Ca}_{v} 3.3\right)$ has been revealed [17]. At 
low voltages, $\mathrm{T}$-type $\mathrm{Ca}^{2+}$ channels are known to mediate a "window current" [18], i.e. a sustained inward $\mathrm{Ca}^{2+}$ current carried by the portion of channels that are not completely inactivated. Hence, T-type $\mathrm{Ca}^{2+}$ channels are well suited to regulate $\mathrm{Ca}^{2+}$ oscillations under nonstimulated or resting membrane conditions. This regulation of $\mathrm{Ca}^{2+}$ homeostasis allows T-type $\mathrm{Ca}^{2+}$ channels to control cell proliferation and apoptosis, or death. There are increasing data suggest that the expression of T-type $\mathrm{Ca}^{2+}$ channels is cell cycle-dependent [19-22].

Mibefradil is a potent inhibitor of T-type $\mathrm{Ca}^{2+}$ currents with 10 to 20 times higher selectivity for T-type over Ltype $\mathrm{Ca}^{2+}$ channels [23]. NNC-55-0396, is a structural analog of mibefradil with a higher selectivity for T-type $\mathrm{Ca}^{2+}$ channels, which exerts no effect against high voltage $\mathrm{Ca}^{2+}$ channels at $100 \mu \mathrm{M}$, but inhibits T-type $\mathrm{Ca}^{2+}$ channels in HEK293 cells with a potency comparable to that of mibefradil $\left(\mathrm{IC}_{50}\right.$ values of 6.8 versus $\left.10.1 \mu \mathrm{M}\right)$ [24]. A growing number of reports showed that mibefradil and NNC-55-0396 could prevent human cancer cell proliferation and induce cancer cell apoptosis as a result of its ability to inhibit the function of T-type $\mathrm{Ca}^{2+}$ channels [10-16, 23, 24]. Additionally, mibefradil was FDA-approved for the treatment of ovarian (2007), pancreas (2008), and glioblastoma multiforme (2009) tumors. At present, however, the detailed biological mechanism (s) underlying the anticancer activity of these channel antagonists has not been explored.

In this study, we examined the function of T-type $\mathrm{Ca}^{2+}$ channels in leukemic cell lines. We showed that inhibition of T-type $\mathrm{Ca}^{2+}$ channels with antagonists, mibefradil and NNC-55-0396, led to a decrease in proliferation, and an increase in apoptosis of leukemia cells in vitro, which was preceded by disrupting endoplasmic reticulum (ER) $\mathrm{Ca}^{2+}$ homeostasis. We also demonstrated down-regulating ERK signaling in MOLT-4 cells following the application of T-type $\mathrm{Ca}^{2+}$ channel antagonists. Since human normal blood cells do not express $\mathrm{T}$-type $\mathrm{Ca}^{2+}$ channels, our results suggest that T-type $\mathrm{Ca}^{2+}$ channel inhibitors may be useful in the treatment of acute lymphocytic leukemia (ALL).

\section{Materials and methods \\ Cell culture}

Human leukemic cell lines MOLT-4, Jurkat, Ball, HL60, NB4, HEL, K-562, and U937 were purchased from the American Type Culture Collection (ATCC; Rockville, MD, USA) and were cultured in RPMI 1640 medium containing $10 \%$ heat-inactivated fetal bovine serum (Gibco by Life Technologies, Carlsbad, CA, USA), $1 \%$ pen/strep (MP Biomedicals, Solon, OH, USA) and $2 \mathrm{mM}$ L-glutamine at $37{ }^{\circ} \mathrm{C}$ in $95 \%$ air/ $5 \% \mathrm{CO}_{2}$ with $95 \%$ humidity.

\section{Isolation of human peripheral blood mononuclear cells (PBMCs)}

Whole blood (5-10 ml) was collected from healthy human male and female donors ( $n=8$ each), according to The Code of Ethics of the World Medical Association. Mononuclear cells were isolated with human lymphocyte separation medium (Tbdscience, Tianjin, China) according to manufacturer's instructions. Briefly, PBMCs were separated by centrifugation at $900 \times \mathrm{g}$ for $30 \mathrm{~min}$ at 18 $20{ }^{\circ} \mathrm{C}$ over a Ficoll-Paque PLUS gradient. The resulting PBMC layer was washed twice with nuclease-free $0.9 \%$ $\mathrm{NaCl}$ solution and prepared for RNA isolation.

\section{Reverse transcriptase-polymerase chain reaction (RT-PCR)}

Total cellular RNA was isolated from exponentially growing cells and human PBMCs using RNAsimple Total RNA Kit (TIANGEN Biotech, Beijing, China). Messenger RNA was reverse-transcribed (RT) to cDNA using oligo $(\mathrm{dT})_{15}$ primers and GoScript reverse transcriptase (Promega, Madison, WI, USA). The cDNA product was used as a template for subsequent PCR amplifications for $\alpha 1 \mathrm{G}, \alpha 1 \mathrm{H}$, and $\alpha 1 \mathrm{I}$ subunit, using sequence-specific primers. Primer sequences, product sizes and PCR conditions are summarized in Table 1. PCR analysis was repeated at least three times with the same samples to confirm reproducibility of the results.

\section{Quantitative PCR}

Total RNA $1 \mu \mathrm{g}$ was used to generate cDNA with GoScript reverse transcriptase as above. A $1-\mu \mathrm{l}$ aliquot of each synthesized cDNA was analyzed by Quantitative Real-Time PCR (CFX96 Real-Time System, Bio-Rad, Singapore) using SYBR Green PCR Master Mix (Takara, Dalian, China) according to manufacturer's protocols and message level was determined using the ${ }^{\Delta} C_{t}$ method. Samples were assayed in triplicate for each gene, and the mean expression was used during subsequent analysis. Q-RT-PCR was carried out under the following reaction conditions: stage $1,95{ }^{\circ} \mathrm{C}$ for $30 \mathrm{~s}$ (Rep 1); stage 2, $95^{\circ} \mathrm{C}$ for $5 \mathrm{~s}$ then $60^{\circ} \mathrm{C}$ for $1 \min (\operatorname{Reps} 40)$.

\section{Western blot analysis}

Western blotting was performed as described previously $[25,26]$. Immunoblots were developed with a goat antirabbit horseradish peroxidase-conjugated secondary antibody (1:10,000; Santa Cruz Biotechnology, Santa Cruz, CA, USA) incubated for $1 \mathrm{~h}$ at room temperature. Immunoblots were visualized with the ECL immunodetection system (Advansta, Menlo Park, CA, USA). The following primary antibodies were used: anti-Cav3.1(1:200 dilution, rabbit polyclonal, Alomone Labs, Israel), antiCav3.2 (1:200 dilution, rabbit polyclonal, Alomone Labs) and anti- Cav3.3 (1:200 dilution, rabbit polyclonal, Alomone Labs), anti-ERK1/2 and anti-pERK1/2 (1:1000 
Table 1 Oligonucleotides used to amplify transcripts of T-type $\mathrm{Ca}^{2+}$ channel a1 subunits and GAPDH

\begin{tabular}{|c|c|c|c|}
\hline Target & Sequence & Product size(bp) & Temp. \\
\hline \multirow[t]{2}{*}{$\mathrm{a} 1 \mathrm{G}$} & F: 5'-TGCTCTGCTTCTTCGTCTTCTT -3' & 152 & $60.0^{\circ} \mathrm{C}$ \\
\hline & R: 5'-CTCATCCTCGTTCTCTGTCTGGT-3' & & \\
\hline \multirow[t]{2}{*}{$\mathrm{a} 1 \mathrm{H}$} & F: 5'-TTGGGTTCCGTCGGTTCT-3' & 193 & $56.5^{\circ} \mathrm{C}$ \\
\hline & R: 5'-ATGCCCGTAGCCATCTTCA-3' & & \\
\hline \multirow[t]{2}{*}{ a1l } & F: 5'-ATCGGTTATGCTTGGATTGTCA-3' & 203 & $54.0^{\circ} \mathrm{C}$ \\
\hline & R: 5'-TGCTCCCGTTGCTTGGTCTC-3' & & \\
\hline \multirow[t]{2}{*}{ GAPDH } & F: 5'-AGAAGGCTGGGGCTCATTTG-3' & 258 & $57.5^{\circ} \mathrm{C}$ \\
\hline & R: 5'-AGGGGCCATCCACAGTCTTC-3' & & \\
\hline
\end{tabular}

dilution, rabbit polyclonal; Cell Signaling, Beverly, MA, USA), and anti-GAPDH (1:1000 dilution, rabbit polyclonal, Goodhere, Hangzhou, China).

\section{Whole-cell patch-clamp recording}

Whole-cell voltage-clamp recordings were performed by following the procedures as described in our previous studies [27]. For T-current recordings, the cells were superfused with bath solution containing (in $\mathrm{mmol} / \mathrm{L}$ ): 10 HEPES, 110 TEA-Cl, $10 \mathrm{CsCl}, 20 \mathrm{BaCl}_{2}, 10$ glucose, $\mathrm{pH} 7.4$ adjusted with TEA-OH. The resistance of pipettes ranged 3-5 $\mathrm{M} \Omega$ when filled with internal solution containing (in mmol/L): $10 \mathrm{HEPES}, 120 \mathrm{CsCl}, 1$ $\mathrm{MgCl}_{2}, 10$ TEA-Cl, 10 EGTA, $5 \mathrm{Na}_{2}$ ATP, 1.2 Creatine phosphase, $\mathrm{pH} 7.2$ adjusted with $\mathrm{CsOH}$. Liquid junction potential was not compensated. Following whole cell access, the cells were held at- $80 \mathrm{mV}$ with test pulses ranging from $-60 \mathrm{mV}$ to $+60 \mathrm{mV}$ with $10 \mathrm{mV}$ increments.

\section{Cell growth assay}

To determine cell survival and proliferation, cell growth was quantified using the CellTiter 96 AQ One Solution Cell Proliferation Assay Kit (Promega, Madison, WI, USA). Cells were plated in 96-well culture plates at a density of $1-2 \times 10^{4}$ cells/well in $100 \mu \mathrm{L}$ of cell culture media. Cells were treated with different concentrations of mibefradil or NNC-55-0396 (Sigma-Aldrich, St. Louis, MO, USA). After drug exposure, $20 \mu \mathrm{L}$ of CellTiter 96 AQ One Solution Reagent was added to each well and allowed to incubate for $2 \mathrm{~h}$ at $37^{\circ} \mathrm{C}$. The quantity of formazan product formed, which is directly proportional to the number of viable cells, was measured on a MultiMode Microplate Reader (MD SpectraMax M3, CA, USA) at $490 \mathrm{~nm}$ wavelength using a reference filter at $650 \mathrm{~nm}$ wavelength. Viability assays were performed at least three times in independent experiments, using triplicate measurements in each.

\section{RNAi against a1G and $\mathrm{a} 1 \mathrm{H}$}

The target sequence against human both $\mathrm{Ca}_{\mathrm{v}} 3.1$ and $\mathrm{Ca}_{\mathrm{v}} 3.2 \mathrm{~T}$-type $\mathrm{Ca}^{2+}$ channels was designed according to a previous report [12]. RNAi oligonucleotides $\left(\mathrm{Ca}_{\mathrm{v}} 3.1 /\right.$ 3.2, 5' - GCCATCTTCCAGGTCATCACA -3'; negative control scramble sequence, 5'-TTCTCCGAACGTGT CACGT-3') were synthesized by Integrated DNA Technologies and cloned into the lentiviral small interference RNA (siRNA) vector GV115 (GeneChem, Shanghai, China). Transduction of shRNA into the MOLT-4 cells was achieved by a lentiviral infection method. The positive transfected cells were sorted using the flow cell sorter and subjected to the CellTiter 96 AQ One Solution Cell Proliferation Assay. Q-RT-PCR was used to verify that shRNA decreased T-type $\mathrm{Ca}^{2+}$ channel genes expression.

\section{Flow cytometer cell cycle analysis}

Analysis of cell cycle distribution was determined by propidium iodide (PI) staining and flow cytometry according to manufacturer's instructions (Keygen Biotech, Nanjing, China). Briefly, following treatment, approximately $1 \times 10^{6}$ cells were fixed in $70 \%$ ethanol for $2 \mathrm{~h}$ on ice. The cell pellets were washed with PBS and incubated with $100 \mu \mathrm{L}$ RNase A solution for $30 \mathrm{~min}$ at $37{ }^{\circ} \mathrm{C}$. PI $(400 \mu \mathrm{L})$ was then added and allowed to incubate for an additional $30 \mathrm{~min}$ at $4{ }^{\circ} \mathrm{C}$ in dark. DNA content was measured by exciting PI at $488 \mathrm{~nm}$ and measuring the emission at $620 \mathrm{~nm}$, using a flow cytometer (BD Accuri C6, Ann Arbor, MI, USA). Data analysis was carried out using FlowJo software. Each experiment is representative of at least three independent experiments.

\section{Apoptosis assay}

Apoptosis of ALL cells was detected using an annexin $\mathrm{V}$ apoptosis assay, followed by flow cytometry analysis. In brief, cells were harvested following treatment, washed in PBS, and subjected to Annexin V/PI staining according to the manufacturer's protocol (Keygen Biotech, Nanjing, China). The percentage of apoptotic cells was evaluated using flow cytometer (BD Accuri C6). 


\section{Measurement of Intracellular $\mathrm{Ca}^{2+}$ Levels}

Briefly, cells were loaded with $1 \mu \mathrm{M}$ Fluo-4/AM (Invitrogen) for $60 \mathrm{~min}$ at $37{ }^{\circ} \mathrm{C}$ in 1640 medium, washed 3 times with PBS and resuspended in 1640 or calcium-free medium. The loaded cells were measured by flow cytometry in a FACScan (BD Accuri C6) at an excitation wavelength of $488 \mathrm{~nm}$ and an emission wavelength of $520 \mathrm{~nm}$ as described below.

\section{Determination of mitochondrial membrane potential}

Mitochondrial membrane potential, $\psi_{\mathrm{m}}$, was assessed with 5, 5', 6, 6'-tetrachloro-1, 1', 3, 3'-tetraethylbenzimidazolylcarbocyanine iodide fluorescent probe (JC-1) (Beyotime, Nantong, China). The treated and control cells were harvested and incubated with $\mathrm{JC}-1$ for $20 \mathrm{~min}$ at $37{ }^{\circ} \mathrm{C}$ in the dark. The cells were washed and resuspended in $100 \mu \mathrm{L}$ of cold PBS and then analyzed with flow cytometer (BD Accuri C6).

\section{Statistical analysis}

Plots were produced using Origin 7.0 (Microcal Software, Inc., Northampton, MA). Results were compared using unpaired t-tests (for comparing two groups) or one factor ANOVA analysis followed, where appropriate, by Student-Newman-Keuls (for multiple comparisons) post-test. A p-value of less than 0.05 indicated statistically significant differences between observed effects. The results are expressed as mean \pm SEM.

\section{Results}

The expression of T-type $\mathrm{Ca}^{2+}$ channels in human leukemia cell lines and PBMCs

We first examined the expression of T-type $\mathrm{Ca}^{2+}$ channels in human leukemia cell lines (MOLT-4, Jurkat, Ball, HL-60, NB4, HEL, K-562 and U937) using standard reverse transcriptase PCR (RT-PCR). As shown in Fig. 1a, these leukemia cell lines examined expressed mRNA for the T-type $\alpha 1$-subunit except HEL and U937 cells: either $\alpha 1 G$ alone (e.g., Jurkat, Ball, HL-60, and NB4), $\alpha 1 G$ and $\alpha 1 \mathrm{I}$ (K-562), or all three T-type $\alpha 1$ subunits (MOLT-4). We additionally determined the quantitative expression of these channels by qPCR in human leukemia cell lines and human PBMCs. As shown in Table 2, except $\alpha 1 \mathrm{H}$ in MOLT-4 cells showed high level, the expression of T-type $\alpha 1$ subunits in other cells were very weak or negative, while human PBMCs didn't express T-type $\mathrm{Ca}^{2+}$ channels. We also examined the expression of T-type $\mathrm{Ca}^{2+}$ channels in MOLT-4 and Jurkat T cells employing western blot analysis. Both $\mathrm{Ca}_{\mathrm{v}} 3.1$ (very weak) and $\mathrm{Ca}_{\mathrm{v}} 3.2$ subunits were stained in a size of $\sim 260 \mathrm{kD}$ from the cellular extract of MOLT- 4 cells, whereas only $\mathrm{Ca}_{\mathrm{v}} 3.2$ subunit (very weak) was detected in Jurkat cells (Fig. 1b).

To evaluate the functional expression of T-type $\mathrm{Ca}^{2+}$ channels in MOLT-4 T cells, whole-cell patch-clamp recordings were performed to record the T-type $\mathrm{Ca}^{2+}$ current. Using $\mathrm{Ba}^{2+}$ as a charge carrier, the current activated at $-30 \mathrm{mV}$, with peak current at $0 \mathrm{mV}$, and displayed rapid activation and inactivation kinetics (Additional file 1: Figure S1). The amplitude of T-current in MOLT- 4 cells varied between 10 and $20 \mathrm{pA}(n=8)$, and the mean T-current density was $0.69 \pm 0.15 \mathrm{pA} / \mathrm{pF}$. Figure 1c shows that a $\sim 15$ pA T-type $\mathrm{Ca}^{2+}$ current was elicited by a depolarizing pulse at $0 \mathrm{mV}$ when held at $-80 \mathrm{mV}$ (control). After perfusion of $2 \mu \mathrm{M}$ of NNC-55-0396, the T-type $\mathrm{Ca}^{2+}$ current was inhibited by $\sim 70 \%$. In addition, MOLT-4 cells showed a mean resting potential of $-30.5 \pm 1.8 \mathrm{mV}(n=12)$ and membrane capacitance of $14.5 \pm 0.7 \mathrm{pF} \quad(n=15)$. Treatment of $\mathrm{T}$ lymphocytes with mibefradil, a selective inhibitor against T-type $\mathrm{Ca}^{2+}$ channels, blocked $\mathrm{Ca}^{2+}$ influx (Additional file 2: Figure S2). These findings indicate that T-type $\mathrm{Ca}^{2+}$ channels play a significant role in the $\mathrm{Ca}^{2+}$ influx pathways of human leukemia T cell line.

\section{T-type $\mathrm{Ca}^{2+}$ channels blockers reduced the viability of human ALL cells}

Since T-type $\mathrm{Ca}^{2+}$ channels have been previously shown to be involved with cell proliferation, we wanted to examine a putative effect of selective T-type $\mathrm{Ca}^{2+}$ channel antagonists, mibefradil and NNC-55-0396 on the viability of ALL cells. As shown in Fig. 2a and b, the cell viability of both MOLT-4 and Jurkat was suppressed by mibefradil and NNC-55-0396 in a dose-dependent manner after $48 \mathrm{~h}$ treatment. However, mibefradil and NNC-55-0396 exhibited no effect on the growth of U937 and HEL cells which did not express T-type $\mathrm{Ca}^{2+}$ channels (Fig. 2c and d), suggesting that the anti-growth effect of both agents most likely resulted from blocking $\mathrm{T}$-type $\mathrm{Ca}^{2+}$ channels of ALL cells.

To further demonstrate that T-type $\mathrm{Ca}^{2+}$ channels are indeed involved in ALL cell growth, we treated MOLT-4 cells with shRNA targeting to both a1G and a1H (a1G/ $\mathrm{H})$ to knocked down T-type $\mathrm{Ca}^{2+}$ channels. As shown in Fig. 3a, shRNA-transduced cells had significantly lower growth rates compared to the scrambled-shRNA infection and vehicle control group. Together, these results suggest that the functional T-type $\mathrm{Ca}^{2+}$ channels contribute to the growth of human $\mathrm{T}$ cell leukemia lines.

\section{Mibefradil and NNC-55-0396 inhibited ALL cell growth via cell cycle arrest and inducing cell apoptosis}

To address how cell growth was inhibited by mibefradil and NNC-55-0396, cell cycle was examined. Mibefradil and NNC-55-0396 not only reduced the proliferation rate, but also induced apoptosis. After incubation with mibefradil or NNC-55-0396 for $48 \mathrm{~h}$, the percentage of MOLT-4 cells in the G0/G1 phase was significantly enhanced, whereas that in the $S$ phase was markedly 


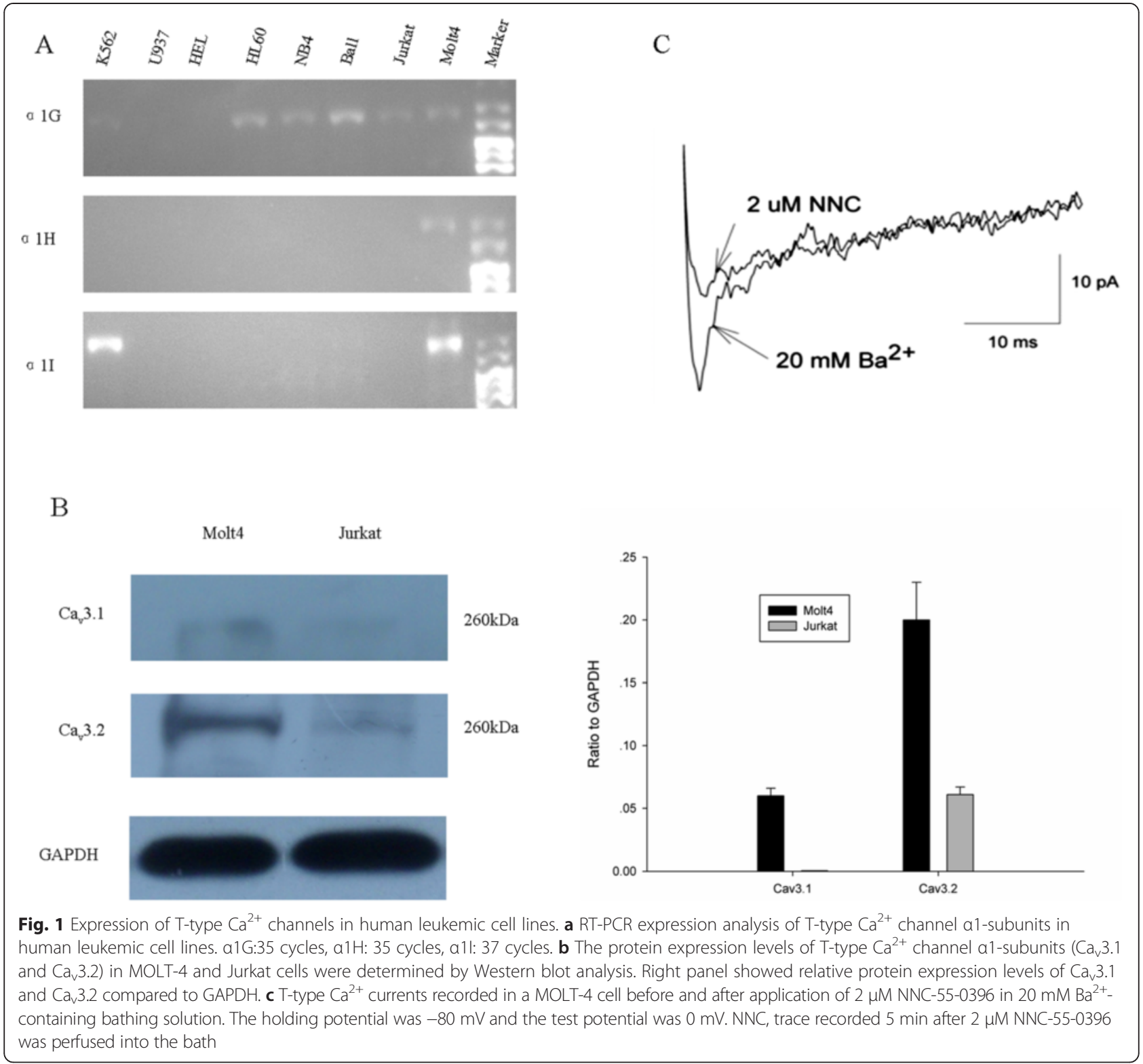

reduced (Fig. $4 \mathrm{~b}$ and c, right panel). Furthermore, both of the T-type $\mathrm{Ca}^{2+}$ channel antagonists induced a remarkable increase in the number of cells at the subG1 phase, a hallmark of cell apoptosis. While in Jurkat cells, mibefradil and NNC-55-0396 mainly induced cell apoptosis confirmed by a significant increase in the percentage of cells at the sub-G1 phase (Fig. 4a and c, left panel). The discrepancy of both antagonists on cell cycle of MOLT-4 and Jurkat cells may arise from the different expression level of T-type $\mathrm{Ca}^{2+}$ channels. The cytotoxicity of both inhibitors was also verified by FACS analysis of Annexin V-FITC and PI stained cells (Fig. 4d and e). In addition, cell death following treatment with both inhibitors was also confirmed by characteristics of apoptosis, such as cell shrinkage and chromatic agglutination (data not shown). Together these results indicate

Table 2 Q-RT-PCR detected T-type $\mathrm{Ca}^{2+}$ channel a1 subunits expression on human leukemic cell lines and PBMCs $\left({ }^{\Delta} \mathrm{Ct}\right.$ )

\begin{tabular}{llllllllll}
\hline Target & MOLT-4 & Jurkat & Ball & NB4 & HL60 & HEL & U937 & K562 & PBMCs \\
\hline a1G & $14.81 \pm 0.57$ & $14.37 \pm 0.25$ & $15.21 \pm 0.27$ & $18.12 \pm 0.34$ & $17.52 \pm 0.31$ & NA, Ct $>40$ & NA, Ct $>40$ & NA, Ct $>40$ & NA, Ct $>40$ \\
a1H & $10.69 \pm 0.43$ & $12.60 \pm 0.39$ & NA, Ct $>40$ & NA, Ct $>40$ & NA, Ct $>40$ & NA, Ct $>40$ & NA, Ct $>40$ & NA, Ct $>40$ & NA, Ct $>40$ \\
a11 & $17.55 \pm 0.66$ & NA, Ct $>40$ & NA, Ct $>40$ & NA, Ct $>40$ & NA, Ct $>40$ & NA, Ct $>40$ & NA, Ct $>40$ & $17.21 \pm 0.36$ & NA, Ct $>40$ \\
\hline
\end{tabular}




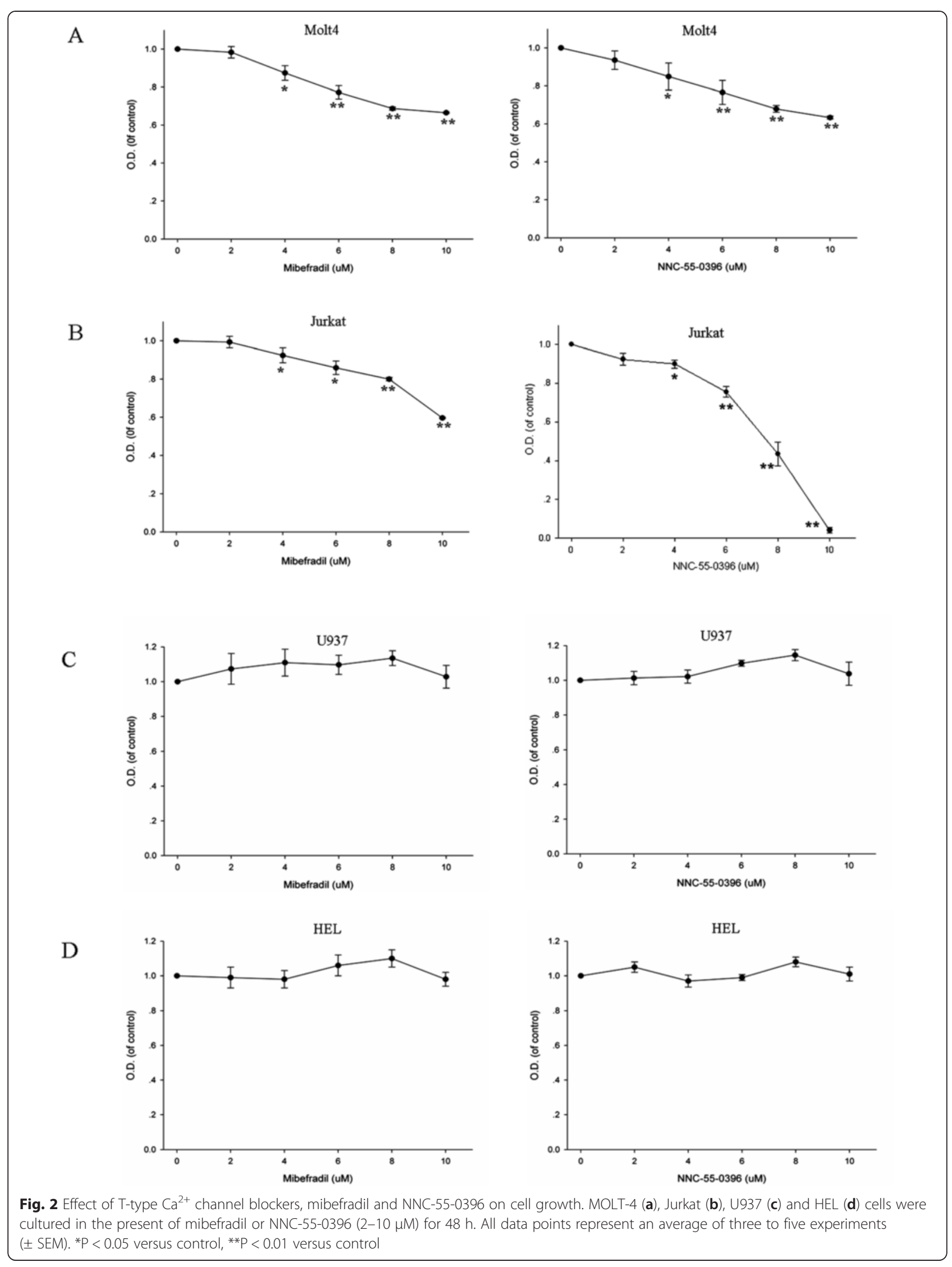


A

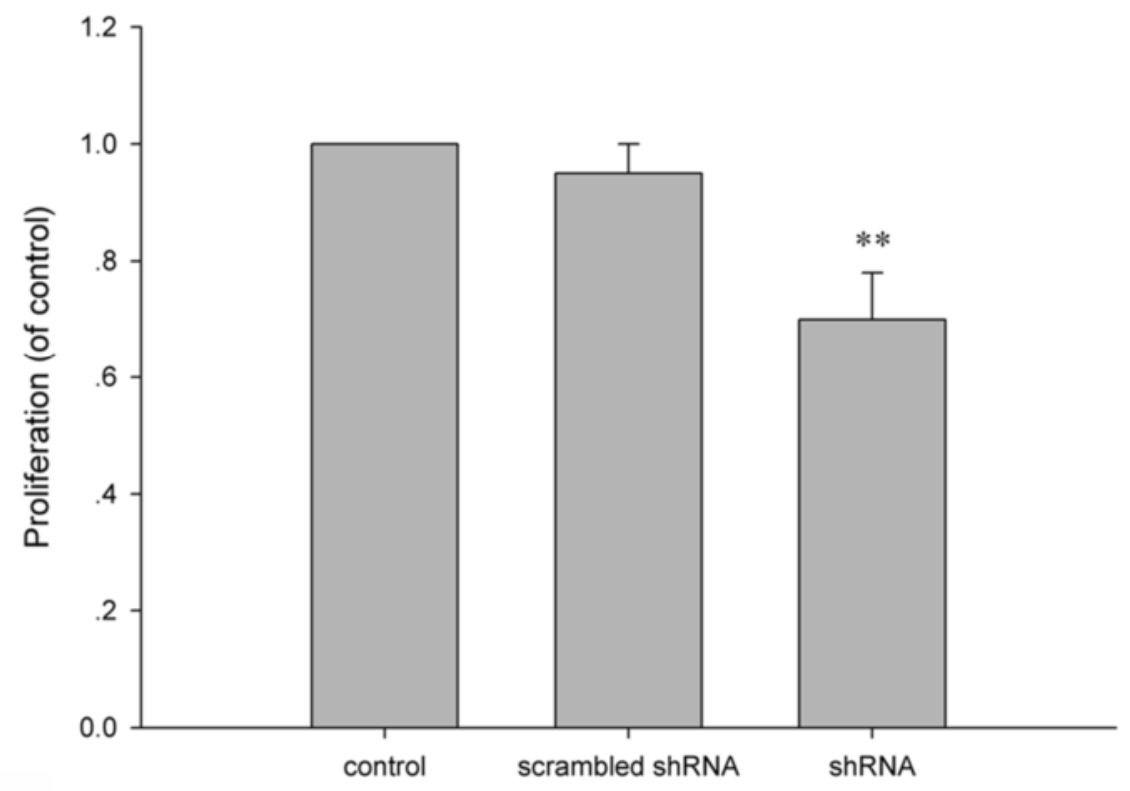

B

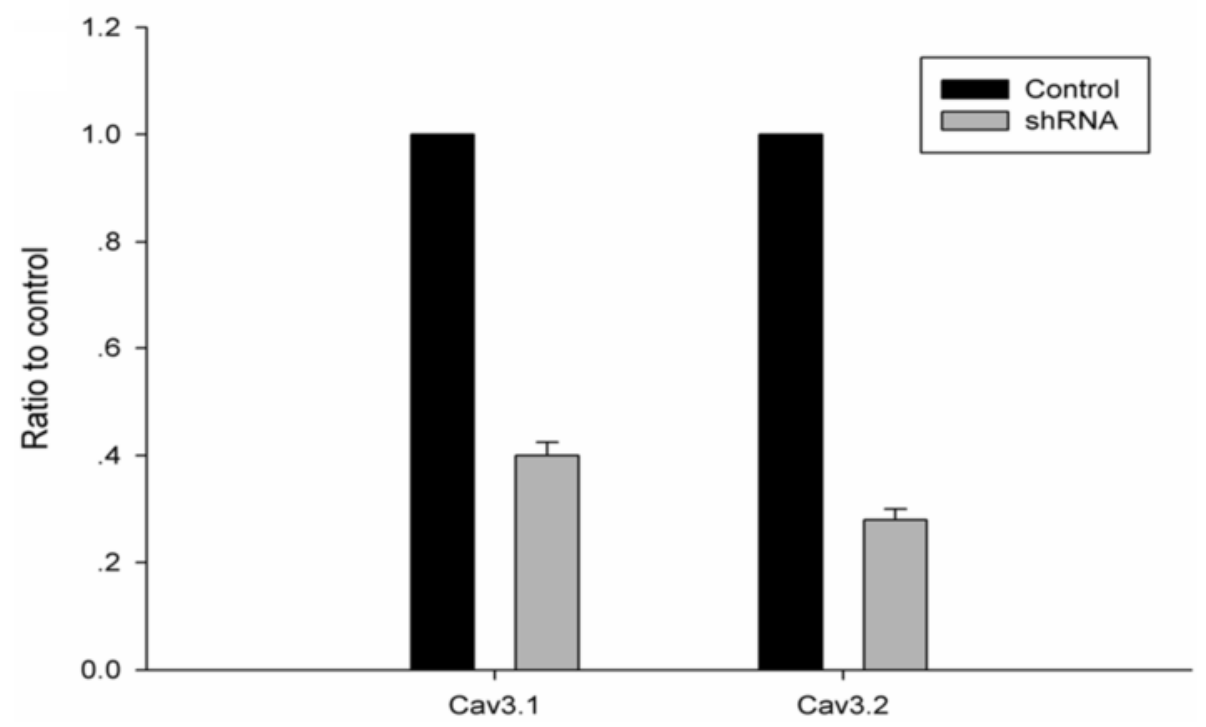

Fig. 3 Effect of shRNA-induced Cav3.1/Ca $3.2-$ gene silencing on MOLT-4 cell growth. a Transduction of shRNA into the MOLT-4 cells was achieved by a lentiviral infection method according to the manufacturer's instructions. Cell growth was observed after $48 \mathrm{~h}$ growth in normal, shRNA-transduced, and scrambled-shRNA infection control group. b Q-PCR analysis of the level of Ca $3.1 / \mathrm{Ca}_{v} 3.2$ knockdown. Data are mean \pm SEM of three independent experiments in triplicates. ${ }^{* *} \mathrm{P}<0.01$ versus scrambled-shRNA control group

that mibefradil and NNC-55-0396 had a dual role on cell viability: (a) blunting proliferation; and (b) promoting cell apoptosis.

\section{Mibefradil and NNC-55-0396 down-regulated ERK signaling} pathway in MOLT-4 cells

It has been reported that $\mathrm{Ca}^{2+}$ can interact with the MAP kinase signaling pathway in $\mathrm{T}$ lymphocytes [28-30], and
MAP kinase signaling pathway plays an important role in regulating cell cycle progression. Therefore we investigated whether T-type $\mathrm{Ca}^{2+}$ channel antagonists, mibefradil and NNC-55-0396 could modulate the expression of the p44/42 MAP kinase in MOLT-4 cells. As shown in Fig. 5b and $\mathrm{c}$, a persistent decrease of phosphorylated ERK1/2 was detected after treatment with either inhibitor, except for a transient enhanced phosphorylation of ERK1/2 after 


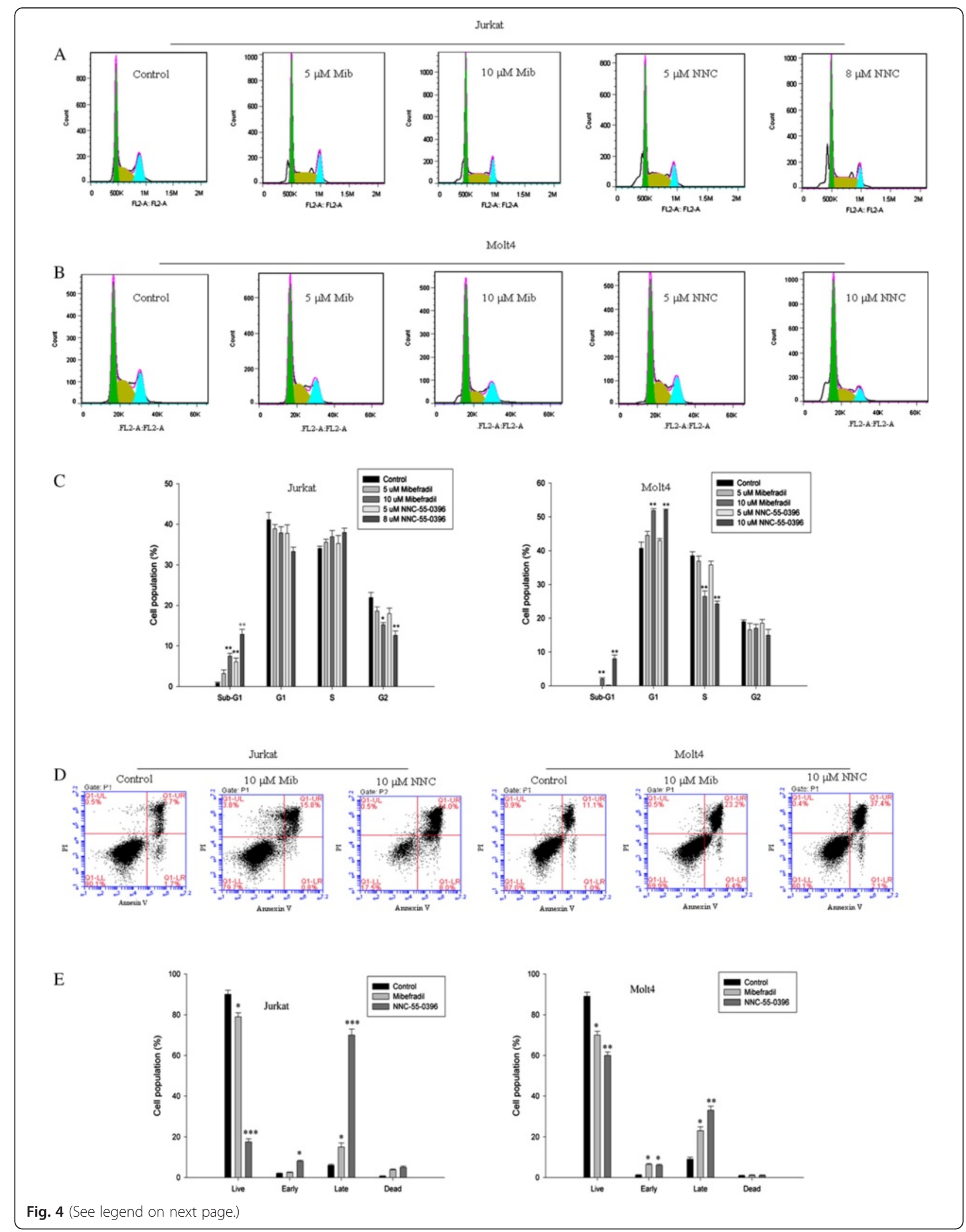


(See figure on previous page.)

Fig. 4 Effect of T-type $\mathrm{Ca}^{2+}$ channel antagonists, mibefradil (Mib) and NNC-55-0396 (NNC), on the cell cycle distribution and cell apoptosis of Jurkat and MOLT-4 cells. a-c Each cell was treated with different concentrations (0, 5 or $10 \mu \mathrm{M})$ of mibefradil or NNC-55-0396 for 48 h. To acquire enough cells for cell cycle analysis, Jurkat cells were treated with 8 MM NNC-55-0396. Cell cycle phase was determined using flow cytometry (FACS). d-e Cells were stained with Annexin V -FITC and propidium iodide (PI) after treatment with $10 \mu \mathrm{M}$ mibefradil or NNC-55-0396 for $48 \mathrm{~h}$ (except Jurkat cells subjected to NNC-55-0396 for 24 h). Flow cytometry profiles represent annexin V-FITC staining in $x$-axis and PI in y-axis for the three experimental conditions. Percentage of each LR and UR area represents Annexin V-positive/PI-negative (early apoptotic) and Annexin V-positive/PI-positive cells (late apoptotic), respectively. Mibefradil and NNC-55-0396 had a dual effect on cell viability: (a) reducing the proliferation rate; and (b) increasing cell apoptosis. $\mathbf{c}$ and e Histogram bars representing the mean \pm SEM of three independent experiments. ${ }^{*} P<0.05,{ }^{* * P}<0.01,{ }^{* * P}<0.001$ versus control group. Statistical significances were determined using one factor ANOVA and Student-Newman-Keuls post-test

NNC-55-0396 treatment. Furthermore, we found that mibefradil and NNC-55-0396 induced the decrease of pERK1/2 in a concentration-dependent manner except $10 \mu \mathrm{M}$ NNC-55-0396, which induced a robust phosphorylation of ERK1/2 (Fig. 5a), in consistent with the $\mathrm{Ca}^{2+}$ overload after $10 \mu \mathrm{M}$ NNC-55-0396 treatment (Additional file 3: Figure S3). These data suggest that mibefradil and NNC-55-03963 could modulate phosphorp44/42 MAP kinase activation via regulating intracellular $\mathrm{Ca}^{2+}$ level, which may contribute to both inhibitor effects on cell growth in ALL cells.

\section{NNC-55-0396 induced endoplasmic reticulum calcium release}

Disruption of intracellular $\mathrm{Ca}^{2+}$ homeostasis is one of the primary processes in the early development of cell injury [31-33], and NNC-55-0396 had stronger cytotoxicity than mibefradil, especially for Jurkat cells. Thus, we examined the effect of NNC-55-0396 on intracellular $\mathrm{Ca}^{2+}$ level in Jurkat cells using flow cytometry. After NNC-55-0396 treatment, a dose-dependent increase in cytosolic $\mathrm{Ca}^{2+}$ concentration was seen in the absence of extracelluar $\mathrm{Ca}^{2+}$ (Fig. 6b). Moreover, low concentration

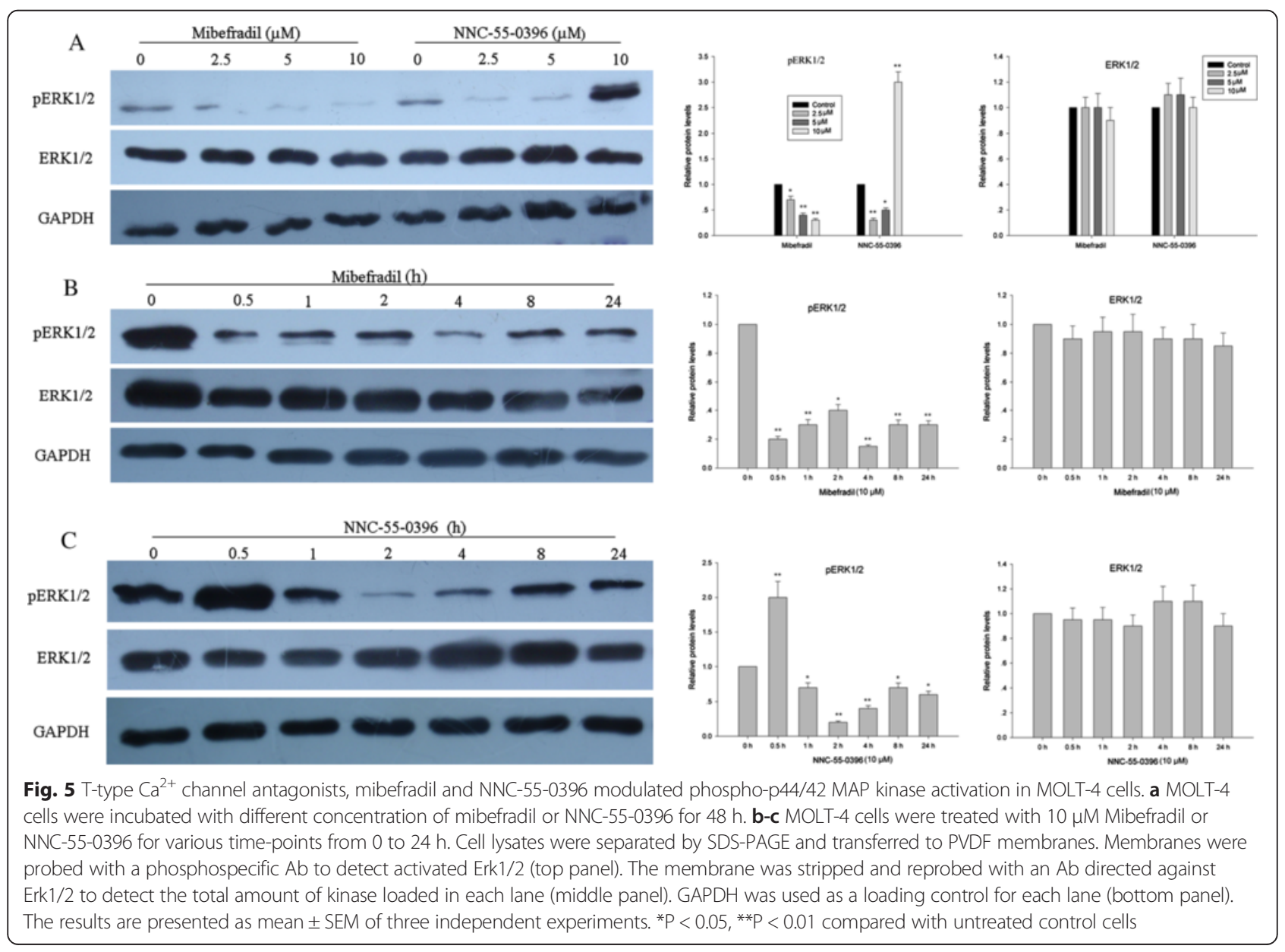


NNC-55-0396 (<5 $\mu \mathrm{M})$ decreased intracellular baseline $\mathrm{Ca}^{2+}$ levels, while high concentration NNC-55-0396 $(>5 \mu \mathrm{M})$ diminished or abolished the inhibiting effect of intracellular baseline $\mathrm{Ca}^{2+}$ levels in the present of extracelluar $\mathrm{Ca}^{2+}$ (Fig. 6a). In addition, $10 \mu \mathrm{M}$ NNC-55-0396 induced sustained $\mathrm{Ca}^{2+}$ overload (Fig. 6a, Green line). In fact, high concentration mibefradil and NNC-55-0396 also induced intracellular $\mathrm{Ca}^{2+}$ overload in MOLT-4 cells (Additional file 3: Figure S3).

Because endoplasmic reticulum (ER) is the major $\mathrm{Ca}^{2+}$ store of intracellular $\mathrm{Ca}^{2+}$, and T-type $\mathrm{Ca}^{2+}$ channels have been suggested to couple $\mathrm{Ca}^{2+}$ influx to ER $\mathrm{Ca}^{2+}$ storage [34], we asked whether NNC-55-0396 would cause a disruption of $\mathrm{Ca}^{2+}$ homeostasis at the ER, ultimately leading to enhanced apoptosis. We first measured whether the response of Jurkat cells to thapsigargin (TG, an agent irreversibly inhibits (sarco) endoplasmic reticulum $\mathrm{Ca}^{2+}$-ATPase (SERCA) and depletes ER $\mathrm{Ca}^{2+}$ stores) could be altered by NNC-55-0396. As shown in Fig. 7, TG-driven increase in $[\mathrm{Ca} 2+] \mathrm{i}$ was attenuated when cells were pretreated with NNC-55-0396. Similar results were obtained with MOLT-4 cells (data not shown). These findings suggest that NNC-55-0396 depletes $\mathrm{Ca}^{2+}$ from the ER.

A proximal target of $\mathrm{Ca}^{2+}$ signals arising from the ER is the mitochondrial network [35]. Several observations underline the significance of the role of this ERmitochondrial $\mathrm{Ca}^{2+}$ flux in stimulating apoptosis [36]. Therefore we decided to address whether NNC-550396-induced ER $\mathrm{Ca}^{2+}$ release had a putative effect on depolarization of the mitochondrial membrane potential, resulting in cell apoptosis. To this end, we first measured the effect of NNC-55-0396 on mitochondrial membrane

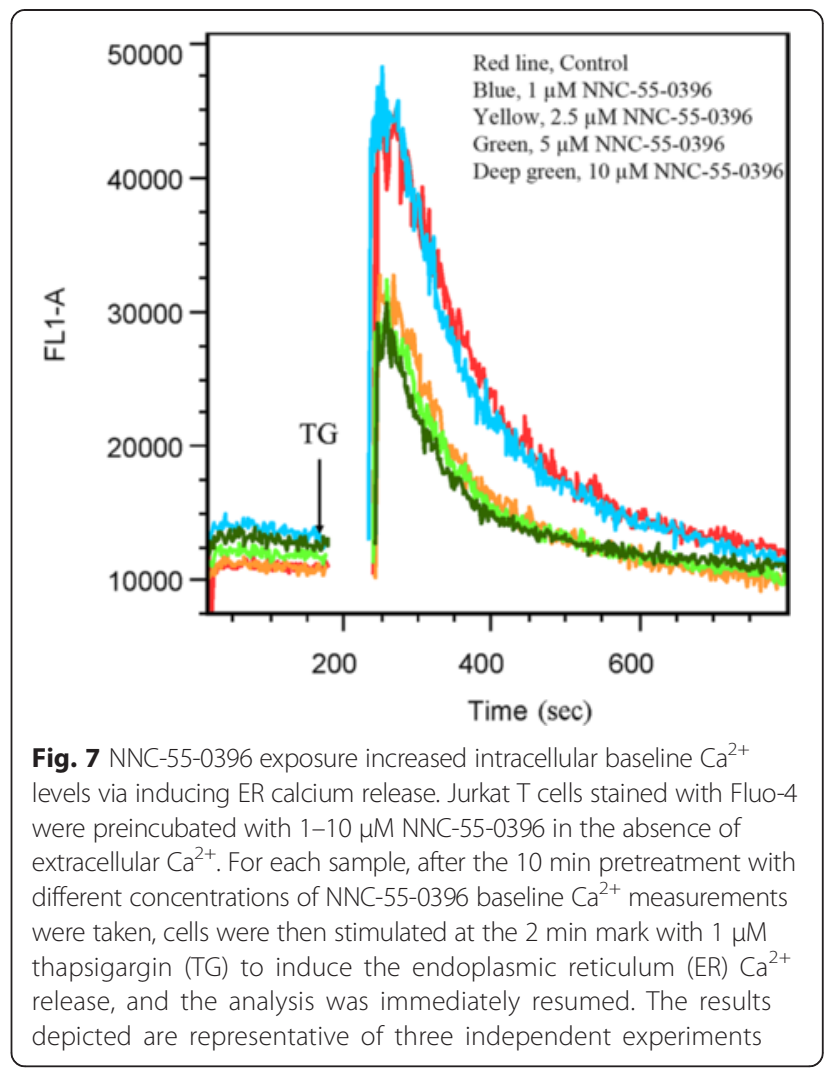

potential in Jurkat cells. As shown in Fig. 8b, NNC-550396 induced depolarization of the mitochondrial membrane potential significantly compared to control after incubation for $2 \mathrm{~h}(\mathrm{P}<0.05)$.

To test whether NNC-55-0396 induced depolarization of the mitochondrial membrane potential arises from ER
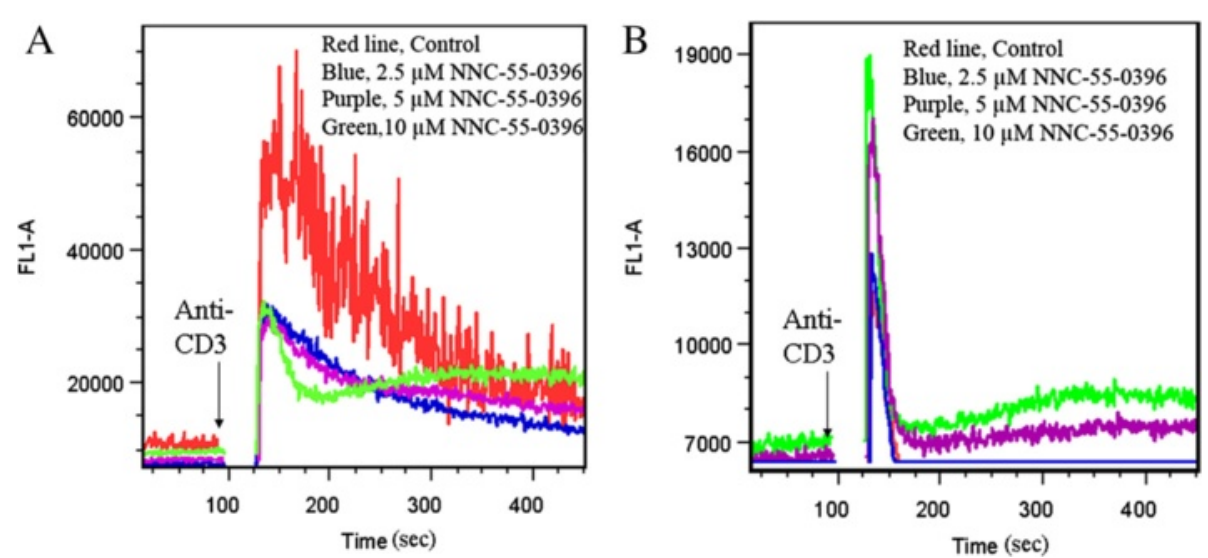

Fig. 6 Effect of T-type Ca ${ }^{2+}$ channel antagonist, NNC-55-0396 on intracellular Ca ${ }^{2+}$ levels in Jurkat T cells. a Jurkat cells stained with Fluo-4 were preincubated with 2.5-10 $\mathrm{MM}$ NNC-55-0396 in the presence of extracellular C $\mathrm{a}^{2+}$. For each sample, after the 10 min treatment with different concentrations of NNC-55-0396 baseline Ca ${ }^{2+}$ measurements were taken, cells were then stimulated at the 2 min mark with $10 \mu \mathrm{g} / \mathrm{ml}$ soluble anti-CD3 monoclonal antibody (mAb), OKT3 (R\&D Systems, Minneapolis, MN, USA) to activate $\mathrm{Ca}^{2+}$ influx, and the analysis was immediately resumed. $\mathbf{b}$ Fluo-4 loaded Jurkat cells were treated with 2.5-10 $\mathrm{MM}$ NNC-55-0396 and stimulated in the absence of extracellular Ca ${ }^{2+}$. Results are representative of 3 independent experiments 


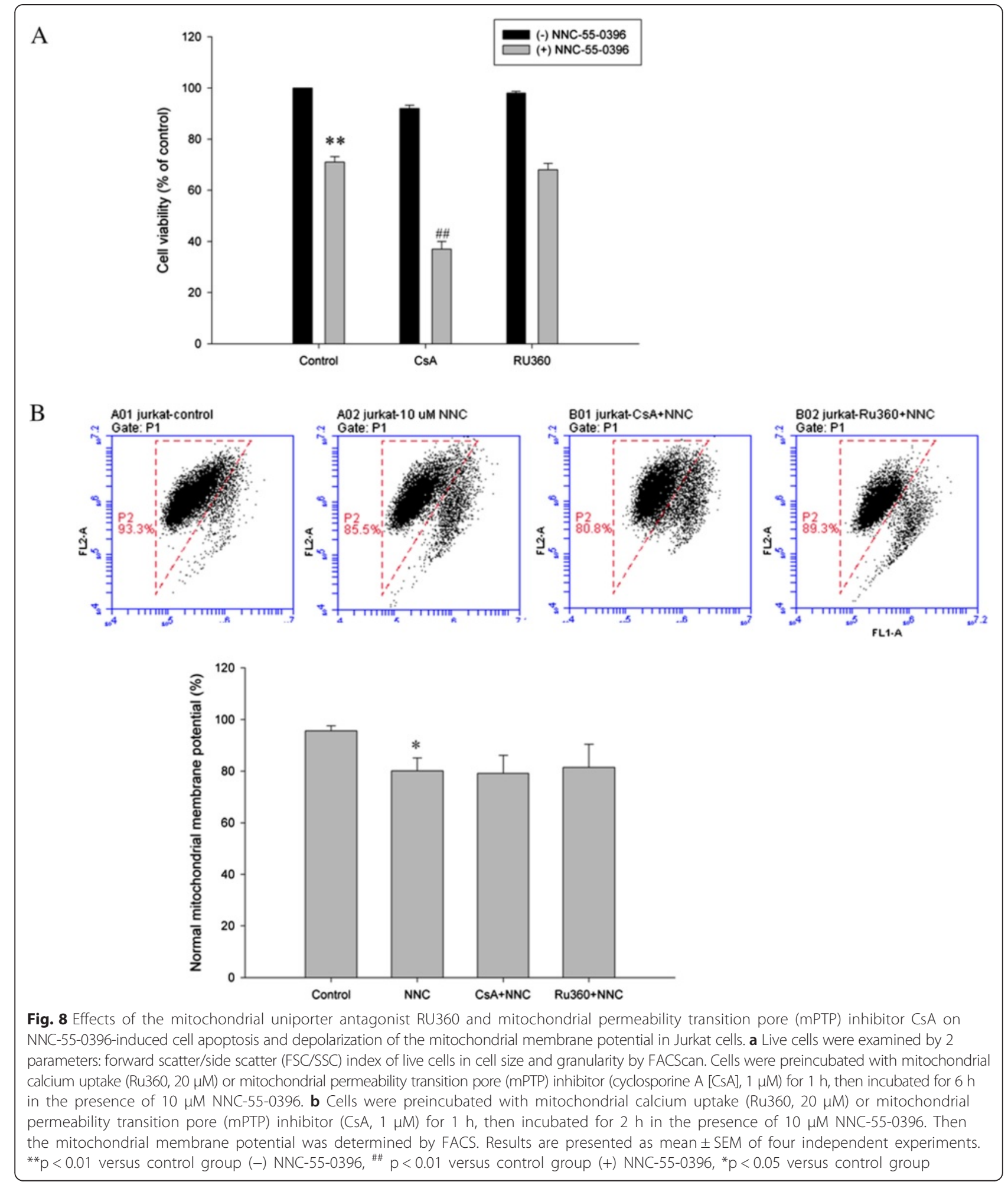

$\mathrm{Ca}^{2+}$ release, which disrupts mitochondrial $\mathrm{Ca}^{2+}$ homeostasis, Ru360 (20 $\mu \mathrm{M}$, mitochondrial calcium uptake inhibitor) or cyclosporine A (CsA, $1 \mu \mathrm{M}$, mitochondrial permeability transition pore ( $\mathrm{mPTP})$ inhibitor) was preincubated with Jurkat cells for $1 \mathrm{~h}$ before NNC-55-0396 treatment. Unexpectedly, neither of the compounds had significantly protective effect on mitochondrial membrane potential (Fig. 8b). In addition, neither of the compounds had any protective effect on cell viability (Fig. 8a). Inversely, CsA enhanced the cytotoxicity of 
NNC-55-0396 in Jurkat cells, may attribute to the inhibition effect of CsA on Calcineurin. In addition, neither of the compounds had any protective effect on mitochondrial membrane potential and cell viability in MOLT-4 cells (Additional file 4: Figure S4). These findings demonstrate that the effect of NNC-55-0396 on depolarization of the mitochondrial membrane potential may not directly depend on $\mathrm{ER} \mathrm{Ca}^{2+}$ release.

\section{Discussion}

In the present investigation, we have identified the expression of T-type $\mathrm{Ca}^{2+}$ channels in human leukemic cell lines. We also demonstrated that $\mathrm{T}$-type $\mathrm{Ca}^{2+}$ channel antagonists, mibefradil and NNC-55-0396 not only reduced the proliferation of ALL cells, but also induced apoptosis. Furthermore, mibefradil and NNC-55-0396 disrupted intracellular calcium homeostasis, partially from ER $\mathrm{Ca}^{2+}$ release. Mibefradil and NNC-55-0396 modulated phospho-p44/42 MAP kinase activation in MOLT$4 \mathrm{~T}$ cells. Our study provides a potential that T-type $\mathrm{Ca}^{2+}$ channels may be a potential target for ALL therapy.

Cancer cells have been reported to be relatively insensitive to reductions in extracellular calcium concentration [37]. $\mathrm{Ca}^{2+}$-dependent signalling is frequently deregulated in cancer cells and, importantly, voltagegated calcium channels (VGCCs) may play a role in remodelling $\mathrm{Ca}^{2+}$ homeostasis. Abnormal up-regulation of the gene encoding $\mathrm{T}$-type $\mathrm{Ca}^{2+}$ channel was detected in various tumour cells [38], suggesting that T-type $\mathrm{Ca}^{2+}$ channels play a role in cancer development.

In the present study, because MOLT- 4 cells expressed high level of T-type $\mathrm{Ca}^{2+}$ channels, they were used for patch-clamp recording analysis. The patch-clamp recording results demonstrate that the current in MOLT-4 cells activated at $-30 \mathrm{mV}$, with peak current at $0 \mathrm{mV}$, inconsistent with other reports of recording $\mathrm{T}$-current $[11,13,39]$. The discrepancy may have arisen from different cell lines used in the study. Furthermore, current-clamp recordings show that the mean resting potential was $-30.5 \pm 1.8 \mathrm{mV}$ in MOLT-4 cells. In addition, the flow cytometric calcium flux assay indicates that cultured T-ALL cells displayed a basal $\mathrm{Ca}^{2+}$ influx which can be reduced by T-type $\mathrm{Ca}^{2+}$ channel blockers. Together, these results are consistent with the occurrence of T-type $\mathrm{Ca}^{2+}$ channel window currents, providing the pattern of $\mathrm{Ca}^{2+}$ signaling required for cell cycle progression.

Several studies with in vitro systems have demonstrated that antagonists of T-type $\mathrm{Ca}^{2+}$ channels reduce cancer cell proliferation and viability [40]. In addition, inhibition of T-type $\mathrm{Ca}^{2+}$ channels with mibefradil had been shown to induce apoptosis in breast cancer cells [41] and glioblastoma cells [10]. This observation supports the idea that T-type $\mathrm{Ca}^{2+}$ channels function as regulators of survival and/or apoptosis signaling. In this study, blocking the functional T-type $\mathrm{Ca}^{2+}$ channels significantly decreased the growth of Jurkat and MOLT4 cells, while mibefradil and NNC-55-0396 had no effect on the growth in U937 and HEL cells, which didn't express T-type $\mathrm{Ca}^{2+}$ channels. These results demonstrate a strong correlation between $\mathrm{T}$ - type $\mathrm{Ca}^{2+}$ channels expression and growth inhibition. Interestingly, we found that the lower-expression cell line (Jurkat) showed a larger growth inhibition than the higher-expressing cell line (MOLT-4), especially for NNC-55-0396 treatment. The phenomenon may attribute to NNC-55-0396-induced $\mathrm{Ca}^{2+}$ release in Jurkat cells, resulting in a larger cell death. In addition, the high percentage of sub-G1 phase upon NNC-55-0396-treatment also indicates that the Jurkat cell death is due to its inherent strong cytotoxicity as well as $\mathrm{T}$-type $\mathrm{Ca}^{2+}$ channel blockade. Cell cycle analysis data demonstrated that mibefradil and NNC-55-0396 had a dual effect on cell viability: (a) decreasing proliferation rate; (b) inducing cell apoptosis. As shown in Fig. 4b and c (right panel), mibefradil and NNC-55-0396 inhibited MOLT-4 cells proliferation rate through a halt in the progression to the G1-S phase.

$\mathrm{Ca}^{2+}$ is an essential regulator of the cell cycle and is indispensable for cell proliferation. For example, the transition from the G1/S interphase (initiation of DNA synthesis) and the G2/M interphase (initiation of mitosis), is dependent upon $\mathrm{Ca}^{2+} /$ calmodulin-dependent kinase II (CaM-kinase II) [42]. In proliferating cells, these $\mathrm{Ca}^{2+}$ signals are often organized in oscillatory patterns involving entry of external $\mathrm{Ca}^{2+}$ and release of $\mathrm{Ca}^{2+}$ from internal stores. T-type $\mathrm{Ca}^{2+}$ channels are particular well suited to participate in such oscillations due to their low voltage activation ranges, transient kinetics of inactivation and "window current". Indeed, many proliferating cells exhibit $\mathrm{T}$-type $\mathrm{Ca}^{2+}$ current, including a variety of tumour cells $[38,40]$. As shown in Additional file 2: Figure $\mathrm{S} 2$ and Fig. 6a, blocking T-type $\mathrm{Ca}^{2+}$ channels with pharmacological blockers reduced intracellular calcium concentration, confirming the role of these channels in calcium concentration maintenance.

Mibefradil was originally presented as a T-type $\mathrm{Ca}^{2+}$ channel blocker and has been used in many studies to establish this putative causal link between T-type $\mathrm{Ca}^{2+}$ channels and cell proliferation. However, mibefradil has also been reported to inhibit cell proliferation through an association with cell swelling and the inhibition of volume-sensitive $\mathrm{Cl}^{-}$channels $[43,44]$ or several other ion channels [45-47]. Son et al. reported that NNC-550396 inhibited voltage-dependent $\mathrm{K}^{+}$channels in rabbit coronary arterial smooth muscle cells [48]. Thus, the inhibitory effects on cell proliferation of non-specific Ttype $\mathrm{Ca}^{2+}$ channel blockers should be carefully attributed to T-type $\mathrm{Ca}^{2+}$ channel blockage. 
In general, the alterations of $\mathrm{Ca}^{2+}$ homeostasis have long been associated with apoptotic cell death [49]. For example, a larger and more prolonged $\mathrm{Ca}^{2+}$ changes $\left(\mathrm{Ca}^{2+}\right.$ surge or $\mathrm{Ca}^{2+}$ overload) could trigger cell death. Therefore, the question arises, why blocking T-type $\mathrm{Ca}^{2+}$ calcium channels, which should inhibit calcium influx from the external environment, paradoxically induces an extensive apoptotic response in ALL cells? One possible explanation lies on the fact that cytosolic $\mathrm{Ca}^{2+}$ can be increased not only through influx from outside, but also via release of calcium ions from the internal stores. As shown in Fig. $6 \mathrm{~b}$ and Fig. 7, NNC-55-0396 could increase cytosolic $\mathrm{Ca}^{2+}$ level from inducing $\mathrm{ER} \mathrm{Ca}^{2+}$ release. In addition, mibefradil at high concentration $(\geq 10 \mu \mathrm{M})$ also induced intracellular $\mathrm{Ca}^{2+}$ overload (Additional file 3: Figure S3). These results are consistent with a recent report that mibefradil at supratherapeutic concentrations $(\geq 10 \mu \mathrm{M})$ induced $\mathrm{Ca}^{2+}$ release from IP3R-operated $\mathrm{Ca}^{2+}$ stores in rat cardiac fibroblasts and human platelets in vitro [50]. Furthermore, the work by Das et al. in melanoma cells demonstrated that mibefradil and pimozide both induce ER stress followed by autophagy, culminating in apoptotic cell death [51]. Valerie et al. reported that targeting T-type $\mathrm{Ca}^{2+}$ channels inhibits mTORC2/Akt pro-survival signaling pathways and induces apoptosis [10]. It appears that both the specificity of the inhibitor and the properties of the model system used may determine the final cellular response to $\mathrm{T}$-type $\mathrm{Ca}^{2+}$ channel blockage: cell cycle arrest, apoptosis, autophagy, necrosis, or any combination of them.

The ER and mitochondria are crucial nodes at which intracellular $\mathrm{Ca}^{2+}$ fluxes are governed and are the principal locations for signaling cell fate choices. In addition, a proximal target of $\mathrm{Ca}^{2+}$ signals arising from the ER is the mitochondrial network. Thus the potential involvement of mitochondria was also determined. It is known that exposure of mitochondria to high $\mathrm{Ca}^{2+}$ concentrations results in their swelling and uncoupling. This phenomenon leads to a loss of maintenance of cellular ATP levels and finally to cell death by necrosis [52]. In our study, Ru360, a specific mitochondrial calcium uptake inhibitor (uniport transporter inhibitor) and cyclosporine A (mPTP inhibitor) were not associated with any effect on NNC-55-0396 toxicity, suggesting that mitochondrial calcium uptake may not be involved in the toxicity in our model. In addition, ER stress, as a result of chronic depletion of $\mathrm{Ca}^{2+}$ from the ER, is also a signal for cell death. The work by Das et al. showed that T-type channel inhibition or down-regulation results in the activation of the IRE1 pathway (giving rise to XBP-1 s) and, possibly, also of the protein kinase RNA-like ER kinase (PERK) or ATF6 pathways of the UPR (inducing GADD153) [51]. Thus ER stress may play an important role in inducing cell apoptosis in our study. Because $\mathrm{Ca}^{2+}$ has close association with MAPK signaling pathway, we next investigated whether mibefradil and NNC-55-0396 can modulate MAP kinase activity. MAP kinase signaling pathway plays an important role in regulating cell cycle progression, and T-type $\mathrm{Ca}^{2+}$ channel inhibitors blunted cell proliferation-through a halt in the progression to the G1-S phase in MOLT-4 cells, so MOLT-4 cells were used as a model to study ERK signaling pathway. We report here that both inhibitors down-regulated ERK signaling pathway in MOLT-4 cells, in agreement with Kotturi report that inhibition of $\mathrm{Ca}^{2+}$ influx decreased the phosphorylation of ERK1/2 [28]. Since ERK1/2 plays an important role in regulating cell proliferation, the inhibition of ERK1/2 signaling pathway may be associated with the proliferation inhibition of MOLT- 4 cells with mibefradil and NNC-55-0396 treatment.

\section{Conclusions}

We have shown both molecular and extensive pharmacological evidence for the presence of a T-type $\mathrm{Ca}^{2+}$ channel in leukemia cell lines. Mibefradil and NNC-550396 had a dual role on cell viability: (a) inhibiting cell proliferation; (b) promoting cell apoptosis. Mechanistically, both T-type $\mathrm{Ca}^{2+}$ channel inhibitors induced ER $\mathrm{Ca}^{2}$ ${ }^{+}$release and disrupted ERK1/2 signaling pathway. Based on these observations and in vivo results reported elsewhere, we propose that T-type $\mathrm{Ca}^{2+}$ channel blockers may be utilized as future therapies for neoplasm expressing T-type channels.

\section{Additional files}

Additional file 1: Electrophysiological recordings from MOLT-4 T cells. (A) Traces showing typical recording of the T-type $\mathrm{Ca}^{2+}$ current $\left(\mathrm{Ba}^{2+}\right.$ current) triggered from a holding potential of $-80 \mathrm{mV}$ to $30 \mathrm{~ms}$-long depolarizing steps at -60 to $+30 \mathrm{mV}$ (10 mV increments) with an interpulse interval of $2 \mathrm{~s}$ in $20 \mathrm{mM} \mathrm{Ba}^{2+}$-containing bathing solution. (B) A plot of the current-voltage relationship for the $\mathrm{Ca}^{2+}$ current recorded as detailed in (A).

Additional file 2: Effect of T-type $\mathrm{Ca}^{2+}$ channel antagonist, mibefradil on intracellular $\mathrm{Ca}^{2+}$ levels in Jurkat $\mathrm{T}$ cells. Jurkat $\mathrm{T}$ cells stained with Fluo-4 were preincubated with 0.5-10 $\mu \mathrm{M}$ mibefradil in the presence of extracellular $\mathrm{Ca}^{2+}$. For each sample, after the $10 \mathrm{~min}$ treatment with different concentrations of mibefradil baseline $\mathrm{Ca}^{2+}$ measurements were taken, cells were then stimulated at the 2 min mark with $10 \mu \mathrm{g} / \mathrm{ml}$ soluble anti-CD3 monoclonal antibody (mAb), OKT3 to activate $\mathrm{Ca}^{2+}$ influx and the analysis was immediately resumed. Results are representative of 3 independent experiments.

Additional file 3: Effect of T-type $\mathrm{Ca}^{2+}$ channel antagonists, mibefradil and NNC-55-0396 on intracellular $\mathrm{Ca}^{2+}$ levels in MOLT-4 T cells. Graphs show the effect of high concentration mibefradil and NNC-55-0396 on the intracellular baseline $\mathrm{Ca}^{2+}$ levels in the presence of extracellular $\mathrm{Ca}^{2+}$. Results are representative of 3 independent experiments.

Additional file 4: Effects of the mitochondrial uniporter antagonist RU360 and mitochondrial permeability transition pore (mPTP) inhibitor CsA on NNC-55-0396-induced cell apoptosis and depolarization of the mitochondrial membrane potential in MOLT-4 cells. (A) Live cells were examined by 2 parameters: forward scatter/side scatter (FSC/SSC) index 
of live cells in cell size and granularity by FACScan. Cells were preincubated with mitochondrial calcium uptake (Ru360, $20 \mu \mathrm{M}$ ) or mitochondrial permeability transition pore (mPTP) inhibitor (cyclosporine $\mathrm{A}[\mathrm{CsA}], 1 \mu \mathrm{M})$ for $1 \mathrm{~h}$, then incubated for $12 \mathrm{~h}$ in the presence of $10 \mu \mathrm{M}$ NNC-55-0396. (B) Cells were preincubated with mitochondrial calcium uptake (Ru360, $20 \mu \mathrm{M}$ ) or mitochondrial permeability transition pore (MPTP) inhibitor (CsA, $1 \mu \mathrm{M})$ for $1 \mathrm{~h}$, then incubated for $8 \mathrm{~h}$ in the presence of $10 \mu \mathrm{M}$ NNC-55-0396. Then the mitochondrial membrane potential was determined by FACS. Results are presented as mean \pm SEM of four independent experiments. ${ }^{* *} p<0.01$ versus control group (-) NNC-55-0396, ${ }^{*} p<0.05$ versus control group.

\section{Abbreviations}

ALL: Acute lymphocytic leukemia; ER: Endoplasmic reticulum; PBMC: Peripheral blood mononuclear cell; PI: Propidium iodide; PERK: RNA-like ER kinase; UPR: Unfolded protein response; TG: Thapsigargin; CSA: Cyclosporine A; VGCC: Voltage-gated calcium channel.

\section{Competing interests}

The authors declare that they have no competing interests.

\section{Authors' contributions}

WFH designed the study, performed the experiments, analyzed the data and wrote the manuscript; $\mathrm{CJ}$ performed experiments; SOY provided technical expertise; $Y Z C$ and $Y W$ provided technical expertise and edited the manuscript. All authors read and approved the final manuscript.

\section{Acknowledgements}

This project was supported by the Chinese National Key Program of Clinical Science (Hematology), the Fujian Provincial Key Laboratory on Hematology Program (No. 2009 J1004), Natural Science Funding of Fujian Province (No. 2013D009), the Department of Health of Fujian Province (No. 2014-CXB-48), the Key Sci-Tech Special Project of Fujian (No. 09ZD001), Scientific Research Foundation for the Young Scholars of Fujian Province (No. 2010-2-112), and Project of Xiamen Municipal Science and Technology Commission (No. 3502Z20134044).

\section{Author details}

${ }^{1}$ Fujian Institute of Hematology, Fujian Medical University Union Hospital, Fuzhou 350004, People's Republic of China. ${ }^{2}$ Department of Blood Transfusion, Maternal and Child Health Hospital of Xiamen, Xiamen 361003, People's Republic of China. ${ }^{3}$ Xiamen Medical Research Institute, Xiamen 361008, People's Republic of China.

\section{Received: 24 March 2015 Accepted: 8 May 2015 Published online: 21 May 2015}

\section{References}

1. Clapham DE. Calcium signaling. Cell. 2007;131:1047-58.

2. Monteith GR, Davis FM, Roberts-Thomson SJ. Calcium channels and pumps in cancer: changes and consequences. J Biol Chem. 2012;287:31666-73.

3. Bergner A, Kellner J, Tufman A, Huber RM. Endoplasmic reticulum Ca2 +-homeostasis is altered in small and non-small cell lung cancer cell lines. J Exp Clin Cancer Res. 2009;28:25.

4. Ciapa B, Pesando D, Wilding M, Whitaker M. Cell-cycle calcium transients driven by cyclic changes in inositol trisphosphate levels. Nature. 1994;368:875-8.

5. Choi DW. lonic dependence of glutamate neurotoxicity. J Neurosci. 1987;7:369-79.

6. Boynton AL, Whitfield JF, Isaacs RJ, Tremblay RG. Different extracellular calcium requirements for proliferation of nonneoplastic, preneoplastic, and neoplastic mouse cells. Cancer Res. 1977;37:2657-61.

7. Toyota M, Ho C, Ohe-Toyota M, Baylin SB, Issa JP. Inactivation of CACNA1G, a T-type calcium channel gene, by aberrant methylation of its $5^{\prime} \mathrm{CpG}$ island in human tumors. Cancer Res. 1999:59:4535-41.

8. Heo JH, Seo HN, Choe YJ, Kim S, Oh CR, Kim YD, et al. T-type Ca2+ channel blockers suppress the growth of human cancer cells. Bioorg Med Chem Lett. 2008;18:3899-901.

9. Li W, Zhang SL, Wang N, Zhang BB, Li M. Blockade of T-type Ca(2+) channels inhibits human ovarian cancer cell proliferation. Cancer Invest. 2011;29:339-46.
10. Valerie NC, Dziegielewska B, Hosing AS, Augustin E, Gray LS, Brautigan DL, et al. Inhibition of T-type calcium channels disrupts Akt signaling and promotes apoptosis in glioblastoma cells. Biochem Pharmacol. 2013;85:888-97.

11. Zhang Y, Zhang J, Jiang D, Zhang D, Qian Z, Liu C, et al. Inhibition of T-type $\mathrm{Ca}(2+)$ channels by endostatin attenuates human glioblastoma cell proliferation and migration. Br J Pharmacol. 2012;166:1247-60.

12. Taylor JT, Huang L, Pottle JE, Liu K, Yang Y, Zeng X, et al. Selective blockade of T-type Ca2+ channels suppresses human breast cancer cell proliferation. Cancer Lett. 2008;267:116-24.

13. Lu F, Chen H, Zhou C, Liu S, Guo M, Chen P, et al. T-type Ca2+ channel expression in human esophageal carcinomas: a functional role in proliferation. Cell Calcium. 2008:43:49-58.

14. Li Y, Liu S, Lu F, Zhang T, Chen H, Wu S, et al. A role of functional T-type Ca2+ channel in hepatocellular carcinoma cell proliferation. Oncol Rep. 2009;22:1229-35.

15. Das A, Pushparaj C, Bahí N, Sorolla A, Herreros J, Pamplona R, et al. Functional expression of voltage-gated calcium channels in human melanoma. Pigment Cell Melanoma Res. 2012;25:200-12.

16. Dziegielewska B, Brautigan DL, Larner JM, Dziegielewski J. T-type Ca2 + channel inhibition induces p53 dependent cell growth arrest and apoptosis through activation of p38-MAPK in colon cancer cells. Mol Cancer Res. 2014;12:348-58.

17. Perez-Reyes E. Molecular physiology of low-voltage-activated t-type calcium channels. Physiol Rev. 2003;83:117-61.

18. Crunelli V, Toth TI, Cope DW, Blethyn K, Hughes SW. The 'window' T-type calcium current in brain dynamics of different behavioural states. J Physiol. 2005;562:121-9.

19. Carbone E, Lux HD. A low voltage-activated calcium conductance in embryonic chick sensory neurons. Biophys J. 1984;46:413-8.

20. McCobb DP, Best PM, Beam KG. Development alters the expression of calcium currents in chick limb motorneurons. Neuron. 1989;2:1633-43.

21. Kostyuk P, Pronchuk N, Savcehnko A, Verkhratsky A. Calcium currents in aged rat dorsal root ganglion neurones. J Physiol. 1993;461:467-83.

22. Xu XP, Best PM. Increase in T-type calcium current in atrial myocytes from adult rats with growth hormone-secreting tumors. Proc Natl Acad Sci U S A. 1990:87:4655-9.

23. Mishra SK, Hermsmeyer K. Selective inhibition of T-type Ca2+ channels by Ro 40-5967. Circ Res. 1994;75:144-8.

24. Huang L, Keyser BM, Tagmose TM, Hansen JB, Taylor JT, Zhuang H, et al. NNC 55-0396 [(1S,2S)-2-(2-(N-[(3-benzimidazol-2-yl)propyl]-N-methylamino) ethyl)-6-fluoro-1,2,3,4-tetrahydro-1-isopropyl-2-naphtyl cyclopropanecarboxylate dihydrochloride]: a new selective inhibitor of

T-type calcium channels. J Pharmacol Exp Ther. 2004;309:193-9.

25. Roger S, Rollin J, Barascu A, Besson P, Raynal PI, lochmann S, et al. Voltage-gated sodium channels potentiate the invasive capacities of human non-small-cell lung cancer cell lines. Int J Biochem Cell Biol. 2007;39:774-86.

26. Zhou B, Chen H, Wei D, Kuang Y, Zhao X, Li G, et al. A novel miR-219-SMC4-JAK2/Stat3 regulatory pathway in human hepatocellular carcinoma. J Exp Clin Cancer Res. 2014;33:55.

27. Huang WF, Ouyang S, Li SY, Lin YF, Ouyang $H$, Zhang $H$, et al. Effect of quercetin on colon contractility and L-type $\mathrm{Ca}(2+)$ channels in colon smooth muscle of guinea-pig. Sheng Li Xue Bao. 2009;61:567-76.

28. Kotturi MF, Carlow DA, Lee JC, Ziltener HJ, Jefferies WA. Identification and functional characterization of voltage-dependent calcium channels in T lymphocytes. J Biol Chem. 2003;278:46949-60.

29. Atherfold PA, Norris MS, Robinson PJ, Gelfand EW, Franklin RA. Calciuminduced ERK activation in human T lymphocytes. Mol Immunol. 1999;36:543-9.

30. Franklin RA, Atherfold PA, McCubrey JA. Calcium-induced ERK activation in human T lymphocytes occurs via p56 (Lck) and CaM-kinase. Mol Immunol. 2000;37:675-83.

31. Orrenius S, Zhivotovsky B, Nicotera P. Regulation of cell death: the calciumapoptosis link. Nat Rev Mol Cell Biol. 2003;4:552-65.

32. Orrenius S, Nicotera P. The calcium ion and cell death. J Neural Transm Suppl. 1994;43:1-11.

33. Berridge MJ, Bootman MD, Lipp P. Calcium-a life and death signal. Nature. 1998;395:645-8.

34. Rossier MF. T channels and steroid biosynthesis: in search of a link with mitochondria. Cell Calcium. 2006:40:155-64.

35. Csordás G, Renken C, Várnai P, Walter L, Weaver D, Buttle KF, et al. Structural and functional features and significance of the physical linkage between ER and mitochondria. J Cell Biol. 2006;174:915-21. 
36. Scorrano L, Oakes SA, Opferman JT, Cheng EH, Sorcinelli MD, Pozzan T, et al. BAX and BAK regulation of endoplasmic reticulum Ca2+: a control point for apoptosis. Science. 2003;300:135-9.

37. Whitfield JF. Calcium signals and cancer. Crit Rev Oncog. 1992;3:55-90.

38. Taylor JT, Zeng XB, Pottle JE, Lee K, Wang AR, Yi SG, et al. Calcium signaling and T-type calcium channels in cancer cell cycling. World J Gastroenterol. 2008;14:4984-91

39. Latour I, Louw DF, Beedle AM, Hamid J, Sutherland GR, Zamponi GW. Expression of T-type calcium channel splice variants in human glioma. Glia. 2004;48:112-9.

40. Panner A, Wurster RD. T-type calcium channels and tumor proliferation. Cell Calcium. 2006;40:253-9.

41. Ohkubo T, Yamazaki J. T-type voltage-activated calcium channel Cav3.1, but not Cav3.2, is involved in the inhibition of proliferation and apoptosis in MCF-7 human breast cancer cells. Int J Oncol. 2012;41:267-75.

42. Kahl CR, Means AR. Regulation of cell cycle progression by calcium/ calmodulin-dependent pathways. Endocr Rev. 2003:24:719-36.

43. Panner A, Cribbs LL, Zainelli GM, Origitano TC, Singh S, Wurster RD. Variation of T-type calcium channel protein expression affects cell division of cultured tumor cells. Cell Calcium. 2005;37:105-19.

44. Steinhardt RA, Alderton J. Intracellular free calcium rise triggers nuclear envelope breakdown in the sea urchin embryo. Nature. 1988;332:364-6.

45. Hsu YF, Lee TS, Lin SY, Hsu SP, Juan SH, Hsu YH, et al. Involvement of Ras/ Raf-1/ERK actions in the magnolol-induced upregulation of p21 and cell-cycle arrest in colon cancer cells. Mol Carcinog. 2007;46:275-83.

46. Tsukamoto I, Kojo S. Effect of calcium channel blockers and trifluoperazine on rat liver regeneration. Eur J Pharmacol. 1987;144:159-62.

47. Fan $\mathrm{H}$, Villegas $\mathrm{C}$, Wright JA. Ribonucleotide reductase $\mathrm{R} 2$ component is a novel malignancy determinant that cooperates with activated oncogenes to determine transformation and malignant potential. Proc Natl Acad Sci U S A. 1996;93:14036-40

48. Son YK, da Hong H, Li H, Kim DJ, Na SH, Park H, et al. The Ca2+ channel inhibitor NNC 55-0396 inhibits voltage-dependent K+ channels in rabbit coronary arterial smooth muscle cells. J Pharmacol Sci. 2014;125:312-9.

49. Rizzuto R, Pinton P, Ferrari D, Chami M, Szabadkai G, Magalhaes PJ, et al. Calcium and apoptosis: facts and hypotheses. Oncogene. 2003;22:8619-27.

50. Eberhard M, Miyagawa K, Hermsmeyer K, Erne P. Effects of mibefradil on intracellular $\mathrm{Ca} 2+$ release in cultured rat cardiac fibroblasts and human platelets. Naunyn Schmiedebergs Arch Pharmacol. 1995;353:94-101.

51. Das A, Pushparaj C, Herreros J, Nager M, Vilella R, Portero M, et al. T-type calcium channel blockers inhibit autophagy and promote apoptosis of malignant melanoma cells. Pigment Cell Melanoma Res. 2013;26:874-85.

52. Halestrap AP. Calcium, mitochondria and reperfusion injury: a pore way to die. Biochem Soc Trans. 2006;34:232-7.

\section{Submit your next manuscript to BioMed Central and take full advantage of:}

- Convenient online submission

- Thorough peer review

- No space constraints or color figure charges

- Immediate publication on acceptance

- Inclusion in PubMed, CAS, Scopus and Google Scholar

- Research which is freely available for redistribution 